JURNAL Midwifery Update (MU)

http://jurnalmu.poltekkes-mataram.ac.id/index.php/jurnalmu

e-ISSN:2684-8511 (Online)

\title{
FAKTOR YANG MEMENGARUHI KEIKUTSERTAAN SUAMI MENJADI AKSEPTOR MOP ( METODE OPERATIF PRIA ) DI DESA MARJANJI KECAMATAN SIPISPIS KABUPATEN SERDANG BEDAGAI TAHUN 2018
}

\author{
Dian Zuiatna \\ Institut Kesehatan Helvetia
}

\begin{abstract}
Abstrak
Pendahuluan: KB merupakan salah satu strategi untuk mengurangi kematian ibu khususnya ibu dengan kondisi 4T, metode kontrasepsi perempuan yang digunakan jauh lebih besar di banding dengan metode kontrasepsi laki-laki, ini menunjukkan bahwa partisipasi laki-laki dalam menggunakan alat kontrasepsi masih sangat kecil. Tujuan dari penelitian ini adalah untuk mengetahui faktor yang memengaruhi keikutsertaan suami menjadi akseptor MOP di Desa Marjanji Kecamatan Sipispis Kabupaten Serdang Bedagai Tahun 2018. Metode: Desain penelitian yang digunakan adalah survey analitik dengan menggunakan desain cros sectional, Populasi yaitu PUS yang ada di dusun I-III berjumlah 355 orang dan pengambilan sampel dengan tehnik inklusi dan eksklusi sebanyak sampel 118 orang. Analisa data menggunakan ujichi-square danregresi linear berganda. Hasil: Dari hasil penelitian menunjukkan bahwa terdapat faktor yang memengaruhi keikutsertaan suami menjadi akseptor MOP, factor Dukungan Istri yang sangat besar pengaruh nya terhadap keikutsertaan suami menjadi akseptor MOP karena semakin dekatnya nilai $p$ 0,000 dengan nilai constant $p 0,000$ semakin besar pengaruhnya terhadap keikut sertaan menjadi akseptor KB MOP. Kesimpulan: Kesimpulan penelitian ini adalah ada faktor yang memengaruhi keikutsertaan suami menjadi akseptor MOP di Desa Marjanji Kecamatan Sipispis Kabupaten Serdang Bedagai Tahun 2018. Di sarankan bagi pasangan usia subur agar mau mencari informasi mengenai vasektomi sehingga pasangan usia subur dapat menambah informasi sehingga pasangan usia subur ikut menjadi akseptor KB MOP.
\end{abstract}

Kata Kunci : Pengetahun, Sumber Informasi, dan Dukungan Istri.

\begin{abstract}
Background : Birth control is one of the strategies to reduce maternal mortality, especially mothers with $4 T$ conditions, the female contraceptive method used is much greater compared to male contraceptive methods, this shows that male participation in using contraception is still very small. The purpose of this study was to determine the factors that influence the participation of husbands into MOP acceptors in Marjanji Village, Sipispis District, SerdangBedagai Regency, 2018. Method: The research design used an analytic survey with a cross sectional design, which aimed to describe the factors that influence the participation of husbands into MOP acceptors. The population, namely fertile agecouple in the hamlet I-III, amounted to 355 people and the sampling in cluts was 78 people, with the inclusion and exclusion techniques amounted 56 people. Data analysis were done by ChiSquare test and multiple linear regression. Result : From the results of the study showed that there were factors that influence the participation of the husband into MOP acceptors, knowledge factors that greatly influence the participation of husbands to become MOP acceptors because the closer the $p .000$ value with constant $p .000$ the greater the effect on participation in becoming a MOP Birth control acceptor. Conclusion: The conclusion of this study is that there are factors that influence the participation of husbands to become MOP acceptors in Marjanji Village, Sipispis Sub-District, SerdangBedagai District, 2018, it is suggested to add good information and counseling about MOP birth control
\end{abstract}

Keywords : Knowledge, Information Sources, and Wife Support. 


\section{PENDAHULUAN}

Visi program Keluarga Berencana Nasional yaitu "Keluarga Berkualitas pada tahun 2015". Visi ini dimaksudkan untuk mewujudkan keluarga yang sejahtera, sehat, maju, mandiri, memiliki jumlah anak yang ideal, berwawasan kedepan, bertanggung jawab, harmonis dan bertaqwa kepada Tuhan Yang Maha Esa. Visi ini juga dimaksudkan untuk mewujudkan partisipasi pria dalam KB dan Kesehatan Reproduksi. Partisipasi pria menjadi penting dalam KB dan kesehatan reproduksi karena pria adalah "patner" dalam reproduksi dan seksual, sehingga sangat beralasan apabila pria dan wanita berbagi tanggung jawab dan berperan secara seimbang untuk mencapai kepuasan kehidupan seksual, pria secara nyata terlibat dalam fertilitas dan mereka mempunyai peranan yang penting dalam memutuskan kontrasepsi yang akan dipakai dan digunakan istrinya serta memberikan dukungan kepada pasangannya terhadap kehidupan reproduksinya (1)

Jumlah penduduk dunia mencapai 7 miliar jiwa pada tahun 2015. Indonesia menempati urutan keempat untuk jumlah penduduk terbesar dunia yaitu 237,6 juta jiwa. Jumlah Penduduk yang besar dan tidak di imbangi dengan pemenuhan kebutuhan serta fasilitas secara umum berdampak terhadap permasalahan-permasalahan sosial. Untuk itu di butuhkan suatu gerakan pengendalian dan peningkatan kesejahteraan penduduk melalui berbagai program- program pemerintah yang salah satunya adalah Gerakan Keluarga Berencana Nasional (BKKBN) (2).

Peserta KB Baru dan KB Aktif di Indonesia pada tahun 2017 menunjukkan pola yang sama dalam pemilihan jenis alat kontrasepsi. Sebagian besar peserta KB Baru dan KB Aktif memilih suntikan dan pil sebagai alat kontrasepsi. Persentase peserta KB Aktif sebesar 74,8\% , Suntikan 47,96\%, Pil 22,81\%, Implan 11,20\%, IUD 10,61\%, Kondom 3,23\%, MOW 3,54\% dan MOP 0,64\%. Persentase Peserta KB Baru 58,93\%, Suntikan 51,53\%, Pil 23,17\%, Implan 11,37\%, IUD 7,23\%, Kondom 4,78\%, MOW 1,73\%, MOP 0,18\%. (3)

Data BKKBN Provinsi Sumatra Utara tahun 2016, Jumlah Peserta KB Baru adalah 350.481 jiwa atau $14,83 \%$ dari PUS yang ada, persentase pengguna alat kontrasepsi oleh peserta KB aktif yang paling dominan adalah pengguna alat kontrasepi suntik yaitu $(45,52 \%)$ dan tidak jauh berbeda pil $(42,41 \%)$, selebihnya menggunakan implant $(20,63 \%)$ dan selebihnya sebanyak $15 \%$ menggunakan alat kontasepsi lainnya seperti IUD,MOP,MOW dan Kondom. (4)

Angka prevalensi pemakaian kontrasepsi di Kabupaten Serdang Bedagai tahun 2016 adalah KB MOW yaitu 4,7\%, MOP yaitu $0,2 \%$, IUD yaitu $6,6 \%$, Implant yaitu $10,1 \%$, Suntik yaitu $53,9 \%$, pil yaitu $22,6 \%$, dan kondom $1,9 \%$ (4).

Data perkiraaan permintaan masyarakat ( PPM ) di UPT Kecamatan Sipispis menjadi peserta KB aktif tahun 2017 jumlah PUS 5121, dengan mix kontrasepsi yaitu IUD sebanyak 120 orang, MOP sebanyak 45 orang, MOW sebanyak 207 orang, Implan sebanyak 304 orang, suntik sebanyak 1159 orang, pil 829 orang, kondom sebanyak 136 orang, MKJP sebanyak 676 orang, non MKJP sebanyak 2124 orang (4). Jumlah kontrasepsi MOP di Desa Marjanji Kecamatan Sipispis, dengan jumlah PUS 680 dan MOP sebanyak 28 orang peserta KB Aktif. Peserta KB baru MOP sebanyak 4 orang pada tahun 2018. Jumlah KB aktif sampai bulan juli tahun 2018 di Kecamatan Sipispis sebanyak 32 orang.

Berdasarkan data tersebut upaya yang dilakukan pemerintah untuk menekan laju pertumbuhan penduduk adalah dengan cara membuat program keluarga berencana. KB merupakan salah satu strategi untuk mengurangi kematian ibu khususnya ibu dengan kondisi $4 \mathrm{~T}$ yaitu Terlalu muda melahirkan (di bawah usia 20 tahun), terlalu sering melahirkan, terlalu dekat jarak melahirkan, dan terlalu tua melahirkan (diatas usia 35 tahun) (5).

Pasangan Usia Subur (PUS), adalah pasangan yang wanitanya berusia antara 15-49 tahun. PUS di harapkan secara bertahap menjadi peserta $\mathrm{KB}$ yang aktif lestari sehingga memberi efek langsung penurunan fertilisasi (6).

Kontrasepsi berasal dari kata kontra dan konsepsi, Kontra berarti "melawan" atau "mencegah", sedangkan konsepsi adalah pertemuan antara sel telur yang matang dengan sperma yang 
mengakibatkan kehamilan (7). Keluarga Berencana adalah tindakan yang membantu individu atau pasutri untuk : mendapatkan objektif-objektif tertentu, menghindari kelahiran yang tidak di inginkan, mendapatkan kelahiran yang di inginkan, mengatur interval di antara kehamilan dan menentukan jumlah anak dalam keluarga (8), maka yang membutuhkan kontrasepsi adalah pasangan yang aktif melakukan hubungan seks dan kedua-duanya memiliki kesuburan normal namun tidak menghendaki kehamilan (9).

Metode kontrasepsi perempuan yang digunakan jauh lebih besar di banding dengan metode kontrasepsi laki-laki, ini menunjukkan bahwa partisipasi laki-laki dalam menggunakan alat kontrasepsi masih sangat kecil. Penggunaan alat kontrasepsi masih dominan dilakukan oleh perempuan. KB bukan hanya di haruskan untuk wanita tetapi juga untuk pria yang di sebut dengan MOP (Metode Operatif Pria) atau Vasektomi. (10).

Rendahnya keikutsertaan pria dalam program KB di karenakan selama ini wanita yang di titikberatkan sebagai sasaran program serta metode KB yang di dominasi dengan metode untuk wanita sehingga membentuk pola pikir para pelaksana program dan masyarakat bahwa karena yang mengalami kehamilan adalah wanita maka, wanita pula yang memiliki kewajiban untuk ber KB. Padahal metode KB wanita lebih banyak menimbulkan efek samping negatif dari pada metode KB pria. Dan kekhawatiran para bapak setelah melakukan vasektomi akan kehilanagan kejantanannya,takut terjadi impotensi, sehingga pria enggan untuk melakukan vasektomi (11).

Rendahnya partisipasi pria/suami dalam progranm KB dan Kesehatan Reproduksi pada prinsipnya berhubungan dengan faktor yaitu kondisi lingkungan sosial, budaya dan masyarakat yang masih menggangap partisipasi pria belum atau tidak penting dilakukan, pengetahuan dan kesadaran pria serta dukungan keluarganya dalam ber KB rendah, dan keterbatasan penerimaan serta aksesibilitas terhadap pelayanan KB dan Kesehatan reproduksi pria (12).

Dukungan dari lingkungan keluarga termasuk istri orang tua atau saudara lainnya sangat menentukan keberhasilan penggunaan metode kontrasepsi Metode Operatif Pria (MOP), sedangkan suami yang tidak mendapat dukungan dari istri, maka pengguna kontrasepsi Metode Operatif Pria (MOP) akan menurun. Jika dalam hal pria atau suami tidak menggunkan alat kontrasepsi MOP maka akan dapat meningkatkan angka kelahiran yang semakin menigkat hal, hal ini akan bertambah jika di lain pihak istri tidak cocok dalam penggunaan kontrasepsi sehingga tingkat kehamilan akan semangkin tinggi(13).

Survey awal yang penulis lakukan pada bulan Agustus di Desa Marjanji Kecamatan Sipispis Kabupaten Serdang Bedagai tahun 2018 dengan mewawancarai 10 pasangan usia subur. Berdasarkan survey tersebut, dari 10 orang yang diwawancarai, 7 orang pria tidak mengetahui tentang vasektomi, 2 orang pria mengetahui tentang vasektomi, tetapi tidak mau melakukan vasektomi, dengan alasan takut, dan istri takut kalau suaminya melakukan MOP, tidak bisa kerja berat, maka istri yang menggunkan $\mathrm{KB}$ suntik, dan KB pil. 1 orang menggunakan $\mathrm{KB}$ vasektomi, dengan alasan tidak ingin punya anak lagi, istri mendukung dan setelah selesai di operasi mereka di beri reward Rp. 150.000, itu sebagai pengganti gaji harian selama istrahat setelah di lakukannya vasektomi.

Berdasarkan latar belakang tersebut maka penulis tertarik untuk mengambil penelitian dengan judul Faktor Yang Memengaruhi Keikutsertaan Suami Menjadi Akseptor MOP di Desa Marjanji Kecamatan Sipispis Kabupaten Serdang Bedagai Tahun 2018.

Tujuan penelitian untuk mengetahui faktor yang memengaruhi keikutsertaan suami menjadi akseptor MOP (Metode Operatif Pria) di Desa Marjanji Kecamatan Sipispis Kabupaten Serdang Bedagai Tahun 2018

\section{METODE PENELITIAN}

Desain penelitian adalah survey analitik dengan pendekatan cross sectional yaitu untuk mengetahui faktor yang mempengaruhi antara variabel yang satu dengan variable yang lain.dalam 
penelitian ini untuk mengetahui faktor yang mempengaruhi ke ikutsertaan suami menjadi akseptor MOP di Desa Marjanji Kecamatan Sipispis Kabupaten Serdang Bedagai tahun 2018 (14).

Lokasi penelitian ini dilakukan di Dusun I-III Desa Marjanji kecamatan Sipispis Kabupaten Serdang, dan Waktu yang diperlukan dalam pelaksanaan penelitian ini, dilakukan dari bulan Juni September tahun 2018.

Populasi dalam penelitian ini adalah pasangan usia subur. Jumlah PUS ada 355 orang yang ada di dusun I-III Desa Marjanji Kecamatan Sipispis Kabupaten Serdang Bedagai tahun 2018 (14), dan Teknik pengambilan sampel dalam penelitian ini adalah asektomi.

Data yang digunakan dalam penelitian ini adalah data primer dan data sekunder,. Tekhnik pengolahan data dalam penelitian ini meliputi coding, tabulating, skoring.

Analisis data menggunakan analisis univariat (distribusi frekuensi), bivariat (Chi-Square) dan multivariat

\section{HASIL}

Karakteristik Responden. Hasil Tabel 1. distribusi frekuensi berdasarkan umur suami dari pasangan usia subur di Dusun I-III Desa Marjanji Kecamatan Sipispis Kabupaten Serdang Bedagai Tahun 2018 diketahui dari 118 responden suami berumur 30 - 39 tahun sebanyak 58 orang $(49,2 \%)$ dan umur $\geq 40$ tahun sebanyak 60 orang $(50,8 \%)$. Berdasarkan pendidikan responden, suami berpendidikan SD sebanyak 34 orang (28,8\%), SMP 26 orang (22\%), SMA sebanyak 50 orang $(42,2 \%)$, PT sebanyak 8 orang $(6,8 \%)$. Berdasarkan suku responden, suku batak sebanyak 29 orang $(24,6 \%)$, jawa 84 orang $(71,2 \%)$, melayu 5 orang $(4,2 \%)$. Berdasarkan Pekerjaan responden, Petani sebanyak 60 orang (50,8\%), karyawan 14 orang 11,9\%), wiraswasta $35(29,7 \%)$ dan PNS sebanyak 9 orang $(7,6 \%)$.

Tabel 1. Karakteristik PUS di dusun I-III Desa Marjanji Kecamatan Sipispis Kabupaten Serdang Bedagai Tahun 2018.

\begin{tabular}{ccc}
\hline Karakteristik Responden & F & $\%$ \\
\hline Umur & 58 & 49,2 \\
30 - 39 Tahun & 60 & 50,8 \\
$\geq 40$ Tahun & & \\
Pendidikan & 34 & 28,8 \\
SD & 26 & 22 \\
SMP & 50 & 42,4 \\
SMA & 8 & 6,8 \\
PT & & \\
Suku & 29 & 24,6 \\
Batak & 84 & 71,2 \\
Jawa & 5 & 4,2 \\
Melayu & & \\
Pekerjaan & 60 & 50,8 \\
Petani & 14 & 11,9 \\
Karyawan & 35 & 29,7 \\
Wiraswasta & 9 & 7,6 \\
PNS & & \\
\hline
\end{tabular}

Analisis Univariat. Hasil tabel 2. distribusi frekuensi berdasarkan pengetahuan suami dari PUS di Dusun I-III Desa Marjanji Kecamatan Sipispis Kabupaten Serdang Bedagai Tahun 2018 diketahui dari 118 responden, suami dari Pasangan Usia Subur berpengetahuan baik tentang KB MOP sebanyak 42 orang (35,6\%), dan suami berpengetahuan kurang tentang KB MOP sebanyak 76 orang 
$(64,4 \%)$, berdasarkan sumber informasi yang di dapat suami di Dusun I-III Desa Marjanji Kecamatan Sipispis Kabupaten Serdang Bedagai Tahun 2018 diketahui dari 118 responden, suami dari Pasangan Usia Subur pernah mendapatkan informasi tentang KB MOP sebanyak 44 orang $(37,3 \%)$, dan suami dari Pasangan Usia Subur yang tidak pernah mendapatkan informasi tentang KB MOP sebanyak 74 orang $(62,7 \%)$, berdasarkan dukungan istri kepada suami tentang KB MOP di Dusun I-III Desa Marjanji Kecamatan Sipispis Kabupaten Serdang Bedagai Tahun 2018 diketahui dari 118 responden, suami dari Pasangan Usia Subur yang istrinya mendukung tentang keikutsertaan suami menjadi akseptor MOP sebanyak 33 orang (28\%), dan kurang mendukung tentang keikutsertaan suami menjadi akseptor MOP sebanyak 85 orang (72\%), dan keikutsertaan suami menjadi akseptor KB MOP di Dusun I-III Desa Marjanji Kecamatan Sipispis Kabupaten Serdang Bedagai Tahun 2018 diketahui dari 118 responden, suami ikutserta menjadi akseptor MOP sebanyak 15 orang $(12,7 \%)$, suami dari Pasangan Usia Subur yang tidak ikutserta menjadi akseptor MOP sebanyak 103 orang (87,3\%).

Tabel 2. Distribusi Frekuensi Pengetahuan Suami, sumber informasi, Dukungan suami, Tentang Keikutsertaan Menjadi Akseptor MOP di Dusun I-III Desa Marjanji Kecamatan Sipispis Kabupaten Serdang Bedagai Tahun 2018

\begin{tabular}{lcc}
\hline \multicolumn{1}{c}{ Variabel } & F & $\%$ \\
\hline Pengetahuan & & \\
Baik & 42 & 35,6 \\
Kurang & 76 & 64,4 \\
Sumber Informasi & & \\
Pernah & 44 & 37,3 \\
Tidak Pernah & 74 & 62,7 \\
Dukungan Istri & & \\
Mendukung & 33 & 28 \\
Kurang Mendukung & 85 & 72 \\
Keikutsertaan Suami Menjadi Akseptor MOP & & \\
Ikutserta & 15 & 87,3 \\
Tidak Ikutserta & 103 & \\
\hline
\end{tabular}

Analisis Bivariat. Hasil tabel 3. dapat di klasifikasikan dari 118 responden mayoritas suami berpengetahuan kurang yaitu sebanyak 76 responden $(64,4 \%)$ dengan keikutsertaan menjadi akseptor KB MOP yaitu 0 dan yang tidak ikutserta yaitu sebanyak 76 orang $(64,4 \%)$, minoritas suami berpengetahuan baik yaitu sebanyak 42 orang $(35,4 \%)$ yang ikutserta menjadi akseptor MOP 15 orang $(12,7 \%)$, yang tidak ikutserta 27 orang $(22,9 \%)$.

Berdasarkan hasil uji statistic Chi-Square di atas memperlihatkan bahwa nilai signifikansi probabilitas pengetahuan suami dengan keikutsertaan menjadi akseptor MOP adalah $0,000<$ nilai sig $\alpha(0,05)$. Hal ini membuktikan bahwa ada hubungan signifikan pengetahuan dengan keikutsertaan suami menjadi akseptor MOP di Dusun I-III Desa Marjanji Kecamatan Sipispis Kabupaten Serdang Bedagai Tahun 2018, dari 118 responden mayoritas suami tidak pernah mendapatkan informasi yaitu sebanyak 74 responden $(62,8 \%)$ dengan keikutsertaan menjadi akseptor KB MOP yaitu sebanyak 4 orang $(3,3 \%)$ dan yang tidak ikutserta yaitu sebanyak 70 orang $(59,3 \%)$, minoritas suami pernah mendapat informasi yaitu sebanyak 44 orang $(37,2 \%)$ yang ikutserta menjadi akseptor MOP 11 orang $(9,3 \%)$, yang tidak ikutserta 33 orang $(27,9 \%)$.

Berdasarkan hasil uji statistic Chi-Square di atas memperlihatkan bahwa nilai signifikansi probabilitas sumber informasi dengan keikutsertaan menjadi akseptor MOP adalah $0,005<$ nilai sig $\alpha$ $(0,05)$. Hal ini membuktikan bahwa ada hubungan signifikan sumber informasi dengan keikutsertaan 
suami menjadi akseptor MOP di Dusun I-III Desa Marjanji Kecamatan Sipispis Kabupaten Serdang Bedagai Tahun 2018, dan dari 118 responden mayoritas suami dengan istri tidak mendukungan yaitu sebanyak 85 responden (72\%) dengan keikutsertaan menjadi akseptor KB MOP yaitu sebanyak 2 orang $(1,6 \%)$ dan yang tidak ikutserta yaitu sebanyak 83 orang $(70,4 \%)$, minoritas suami dengan istri mendukung yaitu sebanyak 33 orang (28\%) yang ikutserta menjadi akseptor MOP 13 orang (11\%), yang tidak ikutserta 20 orang $(17 \%)$.

Berdasarkan hasil uji statistic Chi-Square di atas memperlihatkan bahwa nilai signifikansi probabilitas dukungan istri dengan keikutsertaan menjadi akseptor MOP adalah $0,000<$ nilai sig $\alpha$ $(0,05)$. Hal ini membuktikan bahwa ada hubungan signifikan dukungan istri dengan keikutsertaan suami menjadi akseptor MOP di Dusun I-III Desa Marjanji Kecamatan Sipispis Kabupaten Serdang Bedagai Tahun 2018.

Tabel 3. Tabulasi Silang Hubungan Pengetahuan dan motivasi Ibu Hamil Dengan Kunjungan Antenatal care (ANC) di RB Hanum Medan Tahun 2018.

\begin{tabular}{|c|c|c|c|c|c|c|c|}
\hline \multirow{4}{*}{ Variabel } & \multicolumn{4}{|c|}{ Keikutsertaan Suami Menjadi } & \multirow{3}{*}{ Total } & & \multirow{4}{*}{$p($ Sig) } \\
\hline & & Akse & $\mathrm{r} \mathrm{MO}$ & & & & \\
\hline & \multicolumn{2}{|c|}{ Ikutserta } & \multicolumn{2}{|c|}{ Tidak ikutserta } & & & \\
\hline & $\bar{F}$ & $\%$ & $\mathrm{~F}$ & $\%$ & $\mathrm{~F}$ & $\%$ & \\
\hline \multicolumn{8}{|l|}{ Pengetahuan } \\
\hline Baik & 15 & 12,7 & 27 & 22,9 & 42 & 35,6 & \multirow{2}{*}{0,000} \\
\hline Kurang & 0 & 0 & 76 & 64,4 & 76 & 64,4 & \\
\hline \multicolumn{8}{|l|}{ Sumber Informasi } \\
\hline Pernah & 11 & 9,3 & 33 & 27,9 & 44 & 37,2 & \multirow[t]{2}{*}{0,005} \\
\hline Tidak Pernah & 4 & 3,3 & 70 & 59,3 & 74 & 62,8 & \\
\hline \multicolumn{8}{|l|}{ Dukungan Istri } \\
\hline Mendukung & 13 & 11 & 20 & 17 & 33 & 28 & \multirow[t]{2}{*}{0,000} \\
\hline Tidak Mendukung & 2 & 1,6 & 83 & 70,4 & 85 & 72 & \\
\hline
\end{tabular}

Analisis Multivariat. Tabel 4. Hasil coefficients untuk kategori faktor pengetahuan di peroleh nilai $p 0,012<$ dari a 0,05 , untuk kategori faktor sumber informasi di peroleh nilai $p 0,697>$ dari a 0,05 , untuk kategori faktor dukungan istri di peroleh nilai $p 0,000<$ dari a 0,05 . Dapat disimpulkan faktor dukungan istri yang sangat besar pengaruhnya terhadap keikutsertaan suami menjadi akseptor MOP karena semakin dekatnya nilai $p 0,000$ dengan nilai constant $p 0,000$ semakin besar pengaruhnya terhadap keikutsertaan menjadi akseptor KB MOP.

Tabel 4. Uji Hipotesis regresi Linear dengan Menggunakan Uji-T

Coefficients $^{\mathrm{a}}$

\begin{tabular}{lccccc}
\hline \multirow{2}{*}{ Model } & \multicolumn{2}{c}{ Unstandardized Coefficients } & $\begin{array}{c}\text { Standardized } \\
\text { Coefficients }\end{array}$ & $\mathrm{t}$ & Sig. \\
\cline { 2 - 5 } & $\mathrm{B}$ & Std. Error & Beta & & \\
\cline { 2 - 5 } (Constant) & 2.256 & .058 & & 38.883 & .000 \\
Pengetahuan & -.061 & .024 & -.332 & -2.539 & .012 \\
Sumber_informasi & .013 & .033 & .049 & .391 & .697 \\
Dukunga_Istri & -.111 & .021 & -.420 & -5.184 & .000 \\
\hline
\end{tabular}

a. Dependent Variable: Keikutsertaan_suami 


\section{PEMBAHASAN}

Hubungan Faktor Pengetahuan Terhadap Keikutsertaan Suami Menjadi Akseptor MOP . Berdasarkan table 4.8. tabulasi silang di atas dapat di klasifikasikan dari 118 responden mayoritas suami berpengetahuan kurang yaitu sebanyak 76 responden $(64,4 \%)$ dengan keikutsertaan menjadi akseptor KB MOP yaitu 0 dan yang tidak ikutserta yaitu sebanyak 76 orang $(64,4 \%)$, minoritas suami berpengetahuan baik yaitu sebanyak 42 orang $(35,6 \%)$ yang ikutserta menjadi akseptor MOP 15 orang $(12,7 \%)$, yang tidak ikutserta 27 orang $(22,9 \%)$.

Berdasarkan hasil uji statistic Chi-Square di atas memperlihatkan bahwa nilai signifikansi probabilitas pengetahuan suami dengan keikutsertaan menjadi akseptor MOP adalah $0,000<$ nilai sig $\alpha(0,05)$. Hal ini membuktikan bahwa ada hubungan signifikan pengetahuan dengan keikutsertaan suami menjadi akseptor MOP di Dusun I-III Desa Marjanji Kecamatan Sipispis Kabupaten Serdang Bedagai Tahun 2018.

Menurut penelitian yang telah dilakukan Niken, Faktor-Faktor Yang Berhubungan Dengan Keikutsertaan Suami Menjadi Akseptor Kb Di Desa Sumber Agung Jetis Bantul, jenis penelitian adalah kuantitatif dengan survey analitik dengan desain cross sectionaldiambil dengan metode statifed proportional random sampling. Hasil penelitian ini ada hubungan antara tingkat pengetahuan, tingkat pendidikan, tingkat ekonomi dan informasi dengan keikutsertaan suami menjadi akseptor keluarga berencana $\mathrm{kb}$ di desa sumber agung jetis bandul.(15)

Hasil penelitian ini sejalan dengan penelitian wahyuni tahun 2013, tentang Hubungan Pengetahuan dan Sikap Akseptor KB Pria tentang Vasektomi serta Dukungan Keluarga dengan Partisipasi Pria dalam Vasektomi (Di Kecamatan Tejakula Kabupaten Buleleng). (16)

Hasil penelitian ini sejalan dengan penelitian sulistyaningsih tahun 2014, Hubungan Beberapa Faktor Suami Dengan Keikutsertaan Kb Vasektomi Di Kelurahan Candi Garon Kecamatan Sumowo Tahun 2014. Penelitian ini bersifat ssurvei analitik dengan pendekatan cross sectional. Hasil analisis menunjukkan bahwa ada hubungan pengetahuan dengan partisipasi suami. Dengan $p=0,000(p<0,05)$, ada hubungan dukungan keluarga dengan partisipasi suami dengan $p=0,004 \quad(p<0,05)$, ada hubunganinformasi dengan partisipasi suami dengan $\mathrm{p}=0,029(\mathrm{p}<0,05) \quad(17)$.

Menurut Notoadmojo pengetahuan merupakan hasil tahu, dan ini terjadi setelah orang melakukan penginderaan terhadap sesuatu objek tertentu, penginderaan terjadi melalui panca indera manusia yakni indra penglihatan, pendengaran, penciuman, rasa dan raba sebagian besar pengetahuan manusia diperoleh dari mata dan telinga. Pengetahuan atau kognitif merupakan domain yang sangat penting untuk terbentuknya tindakan seseorang.(18)

Vasektomi adalah tindakan memotong dan menutup saluran mani (vas defens) yang menyalurkan sel mani(sperma) keluar dari pusat produksinya di testis. Cairan semen di produksi dalam vesika seminalis dan prostat sehingga tidak akan terganggu oleh vasektomi.(19)

Pengetahuan menyumbangkan peran dalam menentukan pengambilan keputusan untuk memilih alat kontrasepsi, maka makin meningkat pula perannya sebagai pengambil keputusan. Ketidaktahuan atau kurangnya pengetahuan masyarakat tentang MOP/vasektomi inilah yang merupakan faktor utama penyebab mereka tidak memilih MOP ini sebagai kontrasepsi pilihan. Selain itu metode vasektomi juga masih kurang familier dipahami oleh responden. Kurangnya pengetahuan responden dalam mengetahui keterbatasan vasektomi menjadi salah satu pemicu banyaknya responden yang tidak memilih vasektomi.

Peneliti berasumsi bahwa keikutsertaan responden berhubungan dengan pengetahuan responden dalam berpartisipasi menjadi akseptor keluarga berencana, dari hasil penelitian diperoleh hasil bahwa sebagian besar responden yang berpengetahuan kurang tidak ikutsertaan menjadi akseptor $\mathrm{KB}$, hal ini disebabkan karena responden yang berpengetahuan kurang pernah mendapatkan penyuluhan dan sosialisasi tentang kontrasepsi alat kontrasepsi pria namun penyuluhan tersebut kurang lengkap dan akurat sehingga tidak dapat meningkatkan pengetahuan responden tentang keuntungan dari 
kontrasepsi dan suami tidak termotivasi untuk ikutserta menjadi akseptor KB dalam mensejahterakan keluarganya melalui ber-KB.

Hubungan Faktor Sumber Informasi Terhadap Keikutsertaan Suami Menjadi Akseptor MOP. Berdasarkan table 4.9. tabulasi silang di atas dapat di klasifikasikan dari 118 responden mayoritas suami tidak pernah mendapatkan informasi yaitu sebanyak 74 responden $(62,8 \%)$ dengan keikutsertaan menjadi akseptor KB MOP yaitu sebanyak 4 orang $(3,3 \%)$ dan yang tidak ikutserta yaitu sebanyak 70 orang $(59,3 \%)$, minoritas suami pernah mendapat informasi yaitu sebanyak 44 orang $(37,2 \%)$ yang ikutserta menjadi akseptor MOP 11 orang $(9,3 \%)$, yang tidak ikutserta 33 orang $(27,9 \%)$.

Berdasarkan hasil uji statistic Chi-Square di atas memperlihatkan bahwa nilai signifikansi probabilitas sumber informasi dengan keikutsertaan menjadi akseptor MOP adalah $0,005<$ nilai sig $\alpha$ $(0,05)$. Hal ini membuktikan bahwa ada hubungan signifikan sumber informasi dengan keikutsertaan suami menjadi akseptor MOP di Dusun I-III Desa Marjanji Kecamatan Sipispis Kabupaten Serdang Bedagai Tahun 2018.

Menurut penelitian yang telah di lakukan Agnes yaitu tentang Faktor-faktor yang berhubungan dengan Keikutsertaan suami menjadi akseptor Keluarga Berencana di wilayah kerja Puskesmas Simeulue timur Kecamatan Simeulue Timur Kabupaten Simeulue, penelitian ini bersifat survey analitik dengan pendekatan cross sectional, sampel dalam penelitian ini diambil menggunakan teknik proportional sampling. Ada hubungan informasi dengan partisipasi suami dengan $p=0,029(p<0,05)$.

Hasil penelitian ini sejalan dengan penelitian sulistyaningsih tahun 2014, Hubungan Beberapa Faktor Suami Dengan Keikutsertaan Kb Vasektomi Di Kelurahan Candi Garon Kecamatan Sumowo Tahun 2014. Penelitian ini bersifat ssurvei analitik dengan pendekatan cross sectional. Hasil analisis menunjukkan bahwa ada hubungan pengetahuan dengan partisipasi suami. Dengan $p=0,000(p<0,05)$, ada hubungan dukungan keluarga dengan partisipasi suami dengan $\mathrm{p}=0,004 \quad(\mathrm{p}<0,05)$, ada hubunganinformasi dengan partisipasi suami dengan $\mathrm{p}=0,029(\mathrm{p}<0,05) \quad(17)$.

Sumber Informasi yang diperoleh PUS baik melalui media maupun elektronik akan mempengaruhi suami terhadap pengambilan keputusan dalam pemilihan alat kontrasepsi yang akan digunakan oleh suami, informasi yang diterimanya tentang KB akan menentukan mudah tidaknya suami menyerap dan memahami informasi yang diterimanya, yang kemudian menjadi dipahaminya sehingga informasi tersebut bermanfaat bagi kesejahteraan keluarganya.

Menurut peneliti bahwa sumber informasi berhubungan dengan ikutserta suami menjadi akseptor keluarga berencana, dari hasil penelitian diperoleh hasil bahwa sebagian responden yang pernah mendapatkan informasi tidak ikutserta menjadi akseptor $\mathrm{KB}$, hal ini disebabkan oleh karena informasi yang diperoleh responden kurang, kurang akurat, sehingga kurangnya sumber informasi yang diterima responden baik dari petugas kesehatan, petugas $\mathrm{KB}$, kader dan media cetak, tidak memotivasi suami untuk ikutserta menjadi akseptor KB.

Kurangnya promosi dan sosialisasi tentang KB pria, dimana perempuan masih tetap menjadi sasaran utama sosialisasi program KB dengan harapan istri yang akan mengkomunikasikan pemakaian alat kontrasepsi . Berdasarkan hasil penelitian masih banyak masyarakat yang belum mendapatkan informasi mengenai KB pria. Semakin banyak masyarakat mendapatkan informasi mengenai KB akan semakin banyak kemungkinan suami berpartisipasi dalam program KB.

Suami yang tidak mendapatkan informasi sebanyak 4 orang tetapi mau ikut menjadi akseptor KB MOP karena merasa cukup dengan jumlah anak dan istri mendukung suami untuk melakukan vasektomi, dan suami dari PUS yang mau ikutserta menjadi akseptor MOP walaupun hanya mendapat informasi dari kader, karena gratis dan setelah operasi mereka di beri reward sebesar Rp. 150.000 .

Hubungan Faktor Dukungan Istri Terhadap Keikutsertaan Suami Menjadi Akseptor MOP. Berdasarkan table 4.10. tabulasi silang di atas dapat di klasifikasikan dari 118 responden mayoritas suami dengan istri tidak mendukungan yaitu sebanyak 85 responden (72\%) dengan 
keikutsertaan menjadi akseptor KB MOP yaitu sebanyak 2 orang $(1,6 \%)$ dan yang tidak ikutserta yaitu sebanyak 83 orang $(70,4 \%)$, minoritas suami pernah mendapat informasi yaitu sebanyak 33 orang (28\%) yang ikutserta menjadi akseptor MOP 13 orang (11\%), yang tidak ikutserta 20 orang (17\%).

Berdasarkan hasil uji statistic Chi-Square di atas memperlihatkan bahwa nilai signifikansi probabilitas sumber informasi dengan keikutsertaan menjadi akseptor MOP adalah $0,000<$ nilai sig $\alpha$ $(0,05)$. Hal ini membuktikan bahwa ada hubungan signifikan dukungan istri dengan keikutsertaan suami menjadi akseptor MOP di Dusun I-III Desa Marjanji Kecamatan Sipispis Kabupaten Serdang Bedagai Tahun 2018.

Menurut penelitian Sasmita, tentang hubungan antara pengetahuan, sikap, dukungan istri dengan ketidakikutsertaan suami dalam menggunakan kontrasepsi MOP di wilayah UPTD Pontianak Utara, desain penelitian dalam penelitian ini adalah dengan menggunakan survey analitik dengan rancangan case control, teknik pengambila sampel dalam penelitian ini adalah menggunakan purposive sampling dimana pemilihan kasus ditentukan berdasarkan kriteria yang ditetapkan hasil analisa chi square terbukti variabel yang berhubungan dengan ketidakikutsertaan mop pada pria adalah pengetahuan $(p$ value $=0,035$, or $=3,102)$, sikap $(p$ value $=0,010$, or $=3,846)$, dukungan istri ( $p$ value $=0,000$, or $=9,538) .(20)$

Menurut penelitian dari Ernayati tahun 2015, tentang Tindakan pria peserta KB aktif dalam memilih alat kontrasepsi bagi Keluarga Berencana (KB)(studi deskriptif kualitatif mengenai keikutsertaan pria dalam program KB di Kecamatan Jebres Kota Surakarta). Hasil analisis dengan uji koefisien kontigensi di daptkan nilai $\mathrm{r}=0.336$ dan nilai $p=0.009$. Nilai $p(0.009)<0.05$ maka $\mathrm{H}_{0}$ di tolak (ada hubungan). Hal tersebut menunjukkan adanya hubungan yang signifikan antara dukungan keluarga dengan keikutsertaan akseptor KB pria. Hasil uji kekuatan korelasi menunjukan nilai $\mathrm{r}=$ 0,336.(21)

Dukungan istri merupakan suatu bentuk bantuan atau sokongan dari keluarga dalam bentuk perhatian, penghargaan, dan cinta dalam suatu keluarga. Dukungan yang dimiliki oleh istri dapat membantu suatu masalah yang dihadapi. Seseorang dengan dukungan yang tinggi akan lebih berhasil menghadapi dan mengatasi masalahnya dibanding dengan yang tidak memiliki dukungan. Dukungan istri dapat memperkuat setiap individu, menciptakan kekuatan keluarga, memperbesar penghargaan terhadap diri sendiri. Kurangnya partisipasi istri dalam bentuk dukungan istri kepada penggunaan MOP dikerenakan kurangnya pengetahuan dari istri.

Dukungan istri kepada suami diharapkan dapat memberikan masukan kepada suami bahwa persepsi masalah berKB bukan hanya masalah urusan wanita saja. Tradisi yang masih melekat selama ini adalah bahwa peran perempuan masih terbatas pada pengambilan sikap didalam keluarga, sedangkan suami masih sebagai pengambil keputusan yang dominan serta mempunyai anggapan bahwa suamilah yang harus dihormati dalam pengambilan keputusan karena sudah berlaku umum dalam masyarakat sebagai kepala keluarga

Menurut peneliti semakin baik dukungan istri kepada suami maka semakin besar pula kemungkinan suami untuk bersedia melakukan vasektomi, meskipun setelah istri mendukung, keputusan kembali di tangan suami untuk bersedia atau tidak melakukan vasektomi, begitu juga sebaliknya dukungan istri yang kurang dapat mempengaruhi suami untuk tidak bersedia melakukan vasektomi, hal ini disebabkan adanya anggapan bahwa setelah melakukan vasektomihubungan suami istri tidak akan harmonis lagi dan merasa takut karena dilakukan vasektomi.

Anggapan lain yang berkembang di masyarakat adalah bahwa pria yang telah melakukan vasektomi tidak akan bisa bekerja sepeti biasanya lagi, yaitu melakukan pekerjaan yang berat, sementara mayoritas di Desa Marjanji pekerjaan suami adalah sebagai petani dan kekhawatiran ini mempengaruhi istri tidak mendukung suami melakukan vasektomi.

Faktor Yang Paling Dominan Berpengaruh Terhadap Keikutsertaan Suami Menjadi Akseptor MOP . Berdasarkan tabel 4.13. dari hasil tabel coefficients untuk kategori faktor dukungan 
di peroleh nilai p $0,000<$ dari a 0,05 , faktor dukungan istri yang sangat besar pengaruhnya terhadap keikutsertaan suami menjadi akseptor MOP karena semakin dekatnya nilai $p$ 0,000 dengan nilai constant $p 0,000$ semakin besar pengaruhnya terhadap keikutsertaan menjadi akseptor KB MOP.

Menurut penelitian dari Ernayati tahun 2015, tentang Tindakan pria peserta KB aktif dalam memilih alat kontrasepsi bagi Keluarga Berencana (KB)(studi deskriptif kualitatif mengenai keikutsertaan pria dalam program KB di Kecamatan Jebres Kota Surakarta). Hasil analisis dengan uji koefisien kontigensi di daptkan nilai $\mathrm{r}=0.336$ dan nilai $p=0.009$. Nilai $p(0.009)<0.05$ maka $\mathrm{H}_{0}$ di tolak (ada hubungan). Hal tersebut menunjukkan adanya hubungan yang signifikan antara dukungan keluarga dengan keikutsertaan akseptor KB pria. Hasil uji kekuatan korelasi menunjukan nilai $\mathrm{r}=$ 0,336.(21)

Dukungan istri merupakan suatu bentuk bantuan atau sokongan dari keluarga dalam bentuk perhatian, penghargaan, dan cinta dalam suatu keluarga. Dukungan yang dimiliki oleh istri dapat membantu suatu masalah yang dihadapi. Seseorang dengan dukungan yang tinggi akan lebih berhasil menghadapi dan mengatasi masalahnya dibanding dengan yang tidak memiliki dukungan. Dukungan istri dapat memperkuat setiap individu, menciptakan kekuatan keluarga, memperbesar penghargaan terhadap diri sendiri.

Faktor keluarga termasuk istri merupakan salah satu faktor reinforcing seseorang dalam melakukan tindakan. Namun tidak selamanya faktor reinforcing ini bersikap positif namun ada juga yang bersifatmengharapkan objek tertentu. Sebaliknya bila bersikap negatif maka cenderung akan melakukan tindakan menjauhi, menghindari, membenci dan tidak menyukai objek tertentu. Dalam penentuan sikap yang utuh ini, pengetahuan, pikiran, keyakinan, dan emosional memegang peranan penting. Sehingga diharapkan jika sikapnya baik terhadap kontrasepsi vasektomi maka keinginannya untuk ikut menjadi akseptor vasektomi tersebut menjadi meningkat. Hal ini juga berhubungan dengan tingkat pengetahuan karena pada umumnya responden yang memiliki sikap baik maka pengetahuannya tentang kontrasepsi vasektomi baik

Masih adanya sikap responden yang tidak baik terhadap vasektomi dapat dikarenakan oleh beberapa faktor yang mempengaruhi. Salah satunya adalah kepercayaan akan kontrasepsi yang sudah dipakai. Rata-rata para responden sudah yakin dengan kontrasepsi yang mereka pakai lebih efektif dibandingkan vasektomi. Sikap itu mempunyai 3 komponen pokok yaitu : Kepercayaan (keyakinan), ide dan konsep terhadap suatu objek, kehidupan emosional atau evaluasi terhadap suatu objek, kecenderungan untuk bertindak. Komponen ini secara bersama-sama membentuk sikap yang utuh (total attitude)

Pentingya dukungan istri dalam hal pemilihan alat kontrasepsi yang digunakan selama ini harus mendapatkan persetujuan dari istri terlebih dahulu. Persetujuan istri dalam penentuan penggunaan alat kontrasepsi MOP pada pria diharapkan dapat memberikan gambaran pria dalam melakukan dan memilih penggunaan alat kontrasepsi pria sehingga diharapakan perlunya adanya dukungan istri yang cendrung mendukung terhadap penggunaan MOP dengan harapan dapat menurunkan tingkat pertumbuhan penduduk

\section{KESIMPULAN}

Kesimpulan penelitian ini ada hubungan pengetahuan, sumber informasi dan dukungan istri dengan Keikutsertaan Suami Menjadi Akseptor MOP ( Metode Operatif Pria), dan dukungan istri sangat besar pengaruhnya terhadap keikutsertaan suami menjadi akseptor MOP Di Desa marjanji Kecamatan Sipispis Kabupaten Serdang Bedagai Tahun 2018

\section{SARAN}

Diharapkan kepada petugas kesehatan dan petugas penyuluh keluarga berencana untuk menambah informasi serta memberikan penyuluhan mengenai metode operatif pria (vasektomi) agar 
pasangan usia subur khususnya suami dapat lebih memahami mengenai vasektomi dan bersedia untuk menjadi akseptor KB MOP.

\section{UCAPAN TERIMAKASIH}

Terimakasih peneliti ucapkan kepada Kepala Desa marjanji Kecamatan Sipispis Kabupaten Serdang Bedagai Tahun 2018yang telah memberikan izin serta sarana dan prasarana selama pelaksanaan penelitian, sehingga penelitian berjalan dengan lancar.

\section{DAFTAR PUSTAKA}

1. Anggraini Y M. Pelayanan Keluarga Berencana. Jakarta: Salemba Medika. Yogyakarta; 2016. 55-58 P.

2. Sri Handayani. S.Si T. Buku Ajar Pelayanan Kb (Keluarga Berencana). Yogyakarta; 2017. 94 P.

3. Ministry Of Health Republic Of Indonesia. Health Profile Of Indonesia 2016. Profil Kesehatan Provinsi Bali. 2017. 1-220 P.

4. Syukur P, Maha Y, Kesehatan P, Ri K, Kesehatan P, Kota K, Et Al. Profil Kesehatan Sumatera Utara. 2016;

5. Saifuddin Ab. Buku Panduan Praktis Pelayanan Kontrasepsi. Jakarta; 2013.

6. Gusdianita R, Rahmah R, Yuliana Y. Faktor-Faktor Yang Berhubungan Dalam Pemilihan Jenis Kontrasepsi Efektif Pada Wanita Pasangan Usia Subur Di Wilayah Kerja Puskesmas Rawasari Kota Jambi. J Akad Baiturrahim Jambi. 2018;5(1):72-80.

7. Mulyani Siti Nina. Kb: Keluarga Berencana Dan Kontrasepsi. Yogyakarta; 2013.

8. Pratiwi Ba, Anita B, Angraini W, Puspitasari D. Partisipasi Pria Dalam Penggunaan Metode Kontrasepsi Vasektomi Di Kota Bengkulu. In: Prosiding Seminar Nasional Ikakesmada "Peran Tenaga Kesehatan Dalam Pelaksanaan Sdgs." Fakultas Kesehatan Masyarakat Universitas Ahmad Dahlan; 2017. P. 113-7.

9. Andi Muh M. Kontrasepsi Pria (Studi Perilaku Sosial Terhadap Penerimaan Metode Vasektomi Pada Akseptor Kb Pria Di Kota Makassar). Universitas Negeri Makassar; 2015.

10. Saifuddin Ab. Buku Panduan Praktis Pelayanan Kontrasepsi. Jakarta Yayasan Bina Pustaka Sarwono Prawirohardjo. 2006;

11. Arum Dns, Sujiyatini. Panduan Lengkap Pelayanan Kb Terkini. Jogjakarta; 2017.

12. Suratun Dkk. Pelayanan Keluarga Berencana Dan Kontrasepsi. Jakarta; 2017.

13. Soemanto Rb. Sosiologi Keluarga. 2014;

14. Muhammad I. Panduan Penyusunan Karya Tulis Ilmiah Bidang Kesehatan Menggunakan Metode Ilmiah Hal 92-98. Bandung: Citapustaka Media Perintis; 2016.

15. Setyaningrum N, Melina F. Faktor-Faktor Yang Berhubungan Dengan Keikutsertaan Suami Menjadi Akseptor Kb Di Desa Sumber Agung Jetis Bantul. J Kesehat Samodra Ilmu. $2017 ; 8(1)$.

16. Wahyuni Npds, Suryani N, Murdani K. Hubungan Pengetahuan Dan Sikap Akseptor Kb Pria Tentang Vasektomi Serta Dukungan Keluarga Dengan Partisipasi Pria Dalam Vasektomi (Di Kecamatan Tejakula Kabupaten Buleleng). J Magister Kedokt Kel. 2013;1(1):80-91.

17. Sulistyaningsih S. Hubungan Beberapa Faktor Suami Dengan Keikutsertaan Kb Vasektomi Di Kelurahan Candi Garon Kecamatan Sumowono Tahun 2014. Diponegoro University; 2014.

18. Notoatmodjo S. Pendidikan Dan Perilaku Kesehatan. Jakarta: Rineka Cipta; 2013.

19. Latifa S, Syafei Es. Partisipasi Suami Melakukan Vasektomi. Al-Ahwal J Huk Kel Islam. 2014;7(2):121-34.

20. Sasmita A. Hubungan Antara Pengetahuan Dengan Pemilihan Kontrasepsi Pria (Vasektomi) Di Uptd Puskesmas Kampung Bali Kecamatan Pontianak Kota Tahun 2015. Proners. 2015;3(1). 
21. Ernayati N. Tindakan Pria Peserta Kb Aktif Dalam Memilih Alat Kontrasepsi Bagi Keluarga Berencana $(\mathrm{Kb})$ (Studi Deskriptif Kualitatif Mengenai Keikutsertaan Pria Dalam Program Kb Di Kecamatan Jebres Kota Surakarta). Universitas Sebelas Maret; 2015. 